\title{
Souttar tube for malignant stricture of the oesophagus
}

TW Wong, FHKAM (Emergency Medicine)

Member of the Education and Research Committee, Hong Kong Museum of Medical Sciences Society

https://doi.org/10.12809/hkmj-hkmms202002

The Souttar tube was invented in the 1920 s by Sir Henry Souttar, CBE, (1875-1964) to bypass malignant stricture caused by carcinoma of the oesophagus. Souttar, a surgeon of the London Hospital, became the first surgeon in Britain to perform transauricular digital mitral valvotomy in 1925. He was ahead of his time, because direct heart surgery became acceptable only after the Second World War. He was a versatile general surgeon who also played a leading part in the development of radium therapy and the use of radon seeds to treat cancer. However, it was his early training in engineering at Oxford University that enabled him to design and make new types of surgical instrument. The Souttar tube was among his more famous inventions. ${ }^{1}$

Souttar tubes were typically about $8 \mathrm{~cm}$ long and made from brass wire coiled into a close spiral such that they are extremely flexible but incompressible. The tubes were slightly larger at the upper end to prevent migration. The spiral helped to prevent the tubes from becoming dislodged and lost. An oesophagoscope was used to guide the insertion of a Souttar tube. First, a bougie was used to identify the lumen. Then, the stricture was slowly dilated as far as it was considered safe, probably to a diameter of 8 to $10 \mathrm{~mm}$. A Souttar tube of appropriate size was then passed into position and the oesophagoscope withdrawn. The position could always be verified by an X-ray examination. In general, patients tolerated the tube well and could be fed fluid and soft food. ${ }^{2}$ It was possible to leave the tube in position indefinitely.

The Souttar tubes shown were donated by the Alice Ho Miu Ling Nethersole Hospital to the Hong Kong Museum of Medical Sciences in 1996 (Fig). The tubes were probably acquired by the hospital in the 1950s.

Souttar was not the first to create a tube to bypass malignant stricture in the oesophagus. In 1885, Sir Charters Symonds (1852-1932), a Canadian-born surgeon working at Guy's Hospital in London, created a similar tube. Symonds used a silk suture at the proximal end of the tube to secure it. The suture was brought out of the patient's mouth and attached to the patient's ear. The patient could ingest liquids only with the help of the tube, which would need to be removed for cleaning every 10 days or so. The Souttar tube was an improvement in that it was more comfortable for the patient and also allowed for ingestion of soft food.

The Souttar tube may have been unpopular among Hong Kong surgeons. For example, in a series of 857 patients with squamous cell carcinoma treated

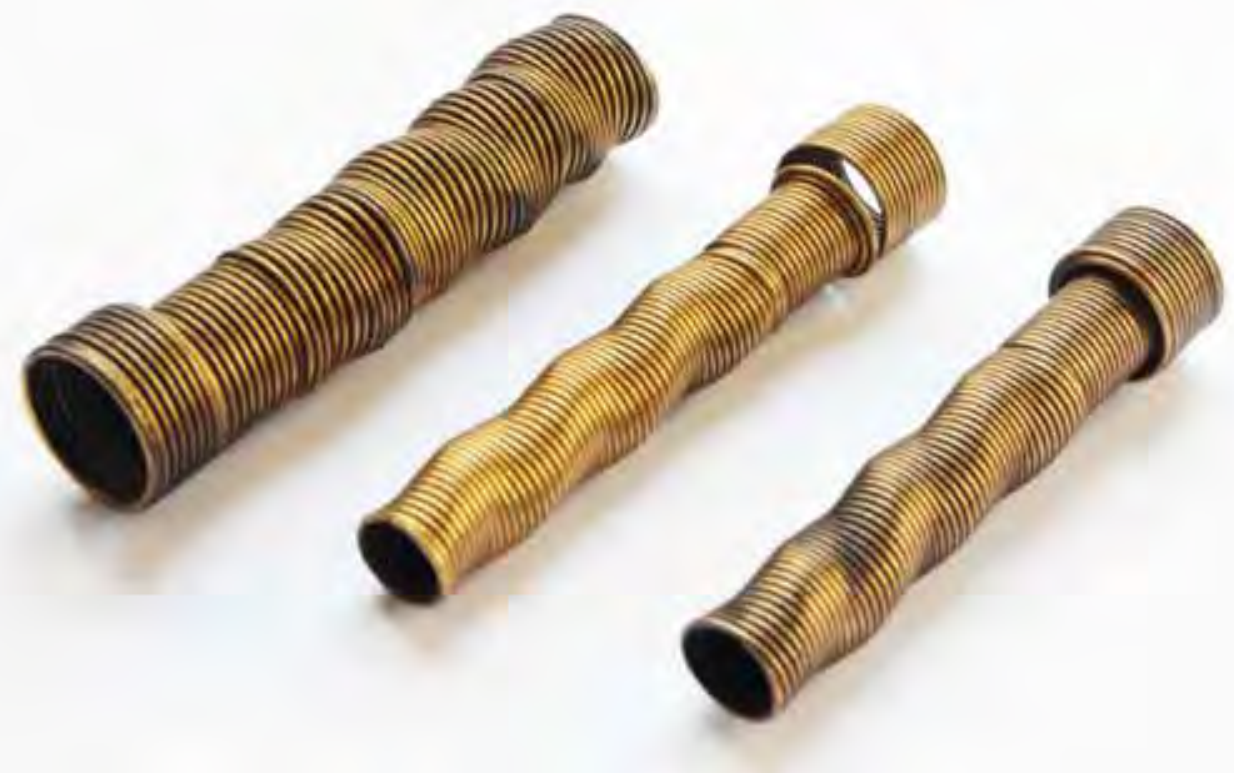


by Queen Mary Hospital between July 1982 and June 1993, 118 patients had bypass surgery versus 22 with stent for palliation. ${ }^{3}$ Furthermore, palliative bypass surgery gave more favourable results than the insertion of an oesophageal tube in several aspects. ${ }^{4}$ First, patients could enjoy regular food instead of a special soft diet. Thus, patients would have better nutrition and psychological satisfaction. The tubes also had some disadvantages, including potential rupture of the oesophagus at the time of introduction and later erosion through the oesophageal wall. The tube could also become obstructed due to tumour growth. ${ }^{4}$ Tubes made of plastic gradually replaced the old metallic tubes. More recently, rigid oesophageal tubes have been replaced by self-expandable metal stents. ${ }^{5}$ Stent insertion-related complications are significantly lower for self-expandable metal stents than for rigid stents. ${ }^{5}$ Nowadays, these new stents are a key tool in the treatment of inoperable malignant stricture of the oesophagus. ${ }^{6}$

\section{References}

1. Campbell M. Sir Henry Souttar. Br Heart J 1965;27:453-4.

2. Souttar HS. A method of intubating the oesophagus for malignant stricture. Br Med J 1924;1:782-3.

3. Fok M, Law SY, Wong J. Operable esophageal carcinoma: Current results from Hong Kong. World J Surg 1994;18:35560.

4. Ong GB. Unresectable carcinoma of the oesophagus. Ann R Coll Surg Engl 1975;56:3-14.

5. Tong D, Law S. Hong Kong experience. In: Ando N, editor. Esophageal Squamous Cell Carcinoma: Diagnosis and Treatment. Tokyo, Japan: Springer; 2015: 261-78.

6. Irani S, Kozarek RA. History of GI stenting: rigid prostheses in the esophagus. In: Kozarek R, Baron T, Song HY, editors. Self-expandable Stents in the Gastrointestinal Tract. New York, NY: Springer; 2012: 3-14. 